[Livingstone, I. (2003). Editorial: Serendipity. New Zealand Annual Review of Education, 12, 1-4]

\section{Editorial: Serendipity}

\section{IAN LIVINGSTONE}

Callithe ll it a happy coincidence, if you will. But the fact that so many of the articles in this issue of the New Zealand Annual Review of Education address matters related to teachers and teaching is significant, in view of the recent establishment of the New Zealand Teachers Council, and its immediate concern with mapping recent initiatives regarding teacher status, and their impact on the profession. Once it has solved the problem of coping with a teacher registration backlog, it has the potential to exercise a very important leadership role in the profession.

But of course, even the word "profession" has been called into question in relation to teaching, and a recent report, ${ }^{1}$ by Marie Cameron, prepared jointly for the Ministry of Education and the Teachers Council, begins at this very point, in clarifying various definitions of the concept of a "profession" in relation to teacher status. It notes the lack of empirical New Zealand research evidence on teacher status, and concludes that professionalism depends ultimately on a common and recognised commitment to a number of things: attracting capable candidates into pre-service teacher education programmes and ensuring that all such programmes are of high quality; putting in place and supporting well-designed teacher induction procedures; generating well-informed school leadership; and providing an attractive working environment in all schools.

It is clear that there is still some way to go in these matters in New Zealand, and proposals to bring a whole diverse range of early childhood institutions into the network, as discussed in the article by Dalli and Te One, increase the challenge enormously. It is, of course, one thing to identify the issues which need addressing, but quite another to set about remedying the complex problems which are bound to emerge. To achieve this, the Teachers Council will need to win the support and confidence of both teachers and the general public. Its current work in developing a Code of Ethics, begun by the previous Teacher Registration Board, will be an important step in this direction.
2 Ian Livingstone

An even more intractable issue, which the Teachers Council will urgently need to address, because of its significant impact on teacher status, is the need to secure a better gender balance across the profession, particularly in the primary schools. An article of my own, Men in Primary Teaching in New Zealand, part of a small book to be published later this year on the topic, examines the issue of the declining numbers of men in primary teaching. This is a world-wide phenomenon in many Western countries, and one of the reasons suggested for it is a perceived decline in the status of teaching over time, which may make it a less attractive career for men. Drawing upon the New Zealand research literature, admittedly rather sparse, the article suggests that, amongst several alternatives which have been advanced, the representational argument is the most compelling in arguing for having a balance of men and women in primary school classrooms. Primary school staff should be more representative of society at large, thereby conveying the message that learning and academic achievement are for everyone.

Carmen Dalli and Sarah Te One pick up the argument in the early childhood sector, and discuss the ten-year government strategic plan Pathways to the Future: Ngā Huarahi Arataki, released in September 2002. Included in this policy statement are three core goals as a focus for government action: increasing participation in quality early child hood education (ECE) services; improving quality of ECE services; and promoting collaborative relationships. The second of these, improving the quality of ECE services, has direct implications for the status of the teachers in early childhood institutions, both community-based and private, and highlights issues yet to be resolved about how their qualifications and training can best be developed.

Kate Thornton considers the area of teacher professionalism, in particular with regard to the effectiveness of the policies of the present Government regarding teacher refresher courses. The literature reveals that while professional development models based in schools and centres are the preferred method of creating change, a balance of approaches is desirable. Teachers should be involved in the design of their own professional development, and the needs of tangata whenua are an important consideration. Teacher refresher courses have historically had some unique features and benefits for teachers, which should be preserved and enhanced.

Since 1999, successful literacy learning for all children has been a focal point of government policy as outlined in the Report of the Literacy Taskforce. Specified in the report is the need to raise standards of achievement for all students as well as to close the gap between high 
and low achievers. To achieve these goals, teachers must be able to understand the nature and function of formative assessment in the teaching/learning process, and also be well equipped to utilise information formatively. A research-based article by Helen Dixon and Ruth Williams, from the Auckland College of Education, concludes that while teachers appear to have increased their theoretical understanding of formative assessment, their descriptions of practice omit a number of critical components which are essential to successful learning for children.

A policy of having at least one article from an overseas author has now been regularised by the Editorial Board. For this issue, Ken Stevens, a former lecturer at Victoria University of Wellington, and currently Professor of Education at Memorial University of Newfoundland, Canada (where he holds the Chair of TeleLearning and Rural Education), has written an article describing how New Zealand and Canada have developed innovative and collaborative ways of delivering education to students in small rural schools in remote communities. A range of computer technologies has been tried, including the Internet, to enable students to share resources and expertise in specialised areas of the secondary curriculum. This again has implications for the professionalism of teachers, who will need to develop new skills and management practices in the integration of on-site and on-line education in each country.

There are two other curriculum pieces which have direct relevance to teachers. Jill Young, a recent MA student in Education at Victoria University of Wellington, provides a historical review of various efforts to introduce sexuality education into primary schools in New Zealand, based on her recent thesis. By exploring key documents and legislation produced over the last 40 years, she highlights the problematic nature of the role of teachers in implementing the syllabus. She argues that the controversy surrounding sex education for primary students resulted in the implementation in the 1980s of a curriculum focusing on the biological process of pubertal change rather than social and emotional issues surrounding sexuality, and discusses the 1999 curriculum document Health and Physical Education in the New Zealand Curriculum.

Joanna Higgins, at the Wellington College of Education, gives a descriptive policy analysis of the Numeracy Development Project in which she has been intimately involved. This project has been heralded as an example of successful transformation of policy to practice, providing evidence of raised student achievement and improved teacher knowledge. Major factors in the success of the implementation of the policy include on-going evaluation, a developing research base from the findings, and the promotion of the concept of a learning community. One again, the part played by teachers in the whole process has been crucial.

Finally, three articles deal with more general policy issues relating to research and education.

Carrie Beaven, a local MEd student, considers the vexed question of school zoning, a key aspect of the Picot Report and Tomorrow's Schools reforms, and examines how this impacts on parental choice in the secondary school sector. Her findings suggest that amendments to the Tomorrow's Schools policy created less choice, rather than more, for some parents, particularly those who were Māori or of low socio-economic status. It is argued that a level of state intervention is required to ensure fair, transparent selection of students in oversubscribed schools in New Zealand's predominantly state school system.

The Review strikes out in a new direction with the record of a dialogue between two staff members at Victoria University of Wellington, Wally Penetito and Kabini Sanga, on the topic of appropriate research strategies in education, based on Māori and Pacific philosophies and practices. They see this as a new endeavour for tertiary institutions in New Zealand, and argue that such courses must be concerned to address the philosophical bases of research at least as rigorously as the actual methods used to investigate matters of enquiry. It is claimed that Māori and Pacific peoples are demanding the sort of research that helps them to survive, to contribute, and "to be" in the world.

Another article with a future look in tertiary education is that by Nick Zepke, from the Wellington campus of the Massey University College of Education. It traces ideas about adult learning from Unesco's Hamburg Declaration (1997) through to the Labour government's Tertiary Education Strategy (2002) and speculates how these ideas might fare over the next five years in a policy context dominated by "third way" politics.

Enjoy!

Notes

Cameron, M. (in press). Teacher Status Project - Stage 1 Research: Identifying teacher status, its impact and recent teacher status initiatives. Report to the Ministry of Education and the New Zealand Teachers Council. 